\title{
Insect Pest Management of Post Harvest Shea Fruits in Storage
}

\author{
T. I. Aneni, ${ }^{1, *}$, V. C. Adaigbe ${ }^{1}$, E. I. Eziashi ${ }^{2}$, O. D. Esiegbuya ${ }^{2}$ \\ ${ }^{1}$ Entomology Division, Nigerian Institute for Oil Palm Research (NIFOR), P.M.B. 1030, Benin-City, Nigeria. \\ ${ }^{2}$ Pathology Division, Nigerian Institute for Oil Palm Research (NIFOR), P.M.B. 1030, Benin-City, Nigeria.
}

\begin{abstract}
How to cite this paper: T. I. Aneni, V. C. Adaigbe, E. I. Eziashi, O. D. Esiegbuya. (2020) Insect Pest Management of Post Harvest Shea Fruits in Storage. International Journal of the Science of Food and Agriculture, 4(3), 330-337. DOI: 10.26855/ijfsa.2020.09.013

Received: August 21, 2020

Accepted: September 15, 2020

Published: September 29, 2020

"Corresponding author: T. I. Aneni, Entomology Division, Nigerian Institute for Oil Palm Research (NIFOR), P.M.B. 1030, Benin-City, Nigeria.

Email: tomaneni1@yahoo.com
\end{abstract}

\begin{abstract}
Insect pests can damage and affect the quality of the shea fruit in storage and this could threaten food security, self sufficiency and incomes. This paper describes approaches to assuring safety throughout the post-harvest storage value chain of the shea fruit. The study area, Niger State, Nigeria, was divided into zones (A-C) for effective coverage of storage warehouses. Selected warehouses were visited, observations conducted, shea fruits collected for laboratory analysis and the owners interviewed on processing and storage methods. The method used emphasized a participatory approach, facilitating greater local involvement in the collection of data that serves the purpose of gaining an insider's perspective. Direct observation of infrastructural facilities also assisted in validating information gained from respondents. Laboratory analysis were conducted on shea fruits for identification and quantification of storage insect pests from October 2014 to September 2015 at Nigerian Institute for Oil Palm Research (NIFOR), with temperatures fluctuating between $26^{\circ} \mathrm{C}-34^{\circ} \mathrm{C}$ and relative humidity from $52 \%-92 \%$. As storage time increased, mites, chalcid ants, and weevils (Curculionidae) were observed. The shea fruits were observed to be mainly attacked by mites and beetles. October (25) and November (21) 2014 had the highest number of mites with fruits severely attacked, and with subsequent decrease observed. Shea fruits should be picked immediately as it matures, as fruits left in the fields for long periods become infested. During collection, it should be ensured that the fruits are not exposed to insect pests before they are properly bagged and removed. All infested shea fruits should be removed and separated immediately. Particular attention should be paid to cracks and gaps where insects may hide on the fruits. The fruits should be properly dried before storage to prevent germination and fungi attack. This study proffers improvement on indigenous storage systems to guarantee long term storage. Information provided will add value to improving insect pest management practices of the shea fruit, thereby leading to improved shea fruit quality.
\end{abstract}

\section{Keywords}

Shea Fruit, Storage Insect Pests, Mites, Management Practices

\section{Introduction}

The Nigerian Institute for Oil Palm Research (NIFOR) represents Nigeria in the African Oil Palm Development Association (AFOPDA), which coordinates collaborative oil palm research and development among African member countries. During its active years of the 1990s, AFOPDA included the shea tree as a crop of interest to the Association since it is a major oil crop for some member countries especially countries of the more arid ecologies. These member 
states created awareness among the Association's member countries including Nigeria, of the numerous potentials of the shea tree and its major economic products. Consequently, NIFOR was mandated by the AFOPDA to provide it with some basic information on its occurrence, distribution and production within the country.

Vitellaria is presently considered a monotypic genus with two subspecies that together populate a 5,000-km stretch of African savanna [1]. Vitellaria paradoxa ssp. nilotica occurs in East Africa, ranging through southern Sudan, northern Uganda, the western fringe of Ethiopia, and the northeast corner of the Democratic Republic of the Congo. Vitellaria paradoxa ssp. paradoxa ranges from the eastern Central African Republic westward to within a few kilometers of the Atlantic coast of Senegal [2]. Africa produces about 1,760,000 tons of raw shea nuts annually from its wild trees [3]. The shea-nut tree, Vitellaria paradoxa Gaertn, is a major component of the woody flora of the Sudan and Guinea savannah vegetation zones of sub-Saharan Africa [4]. V. paradoxa is indigenous to sub-Saharan Africa, and generally only found in semi-arid to arid areas north of the humid forest zone [5]. The most important product of $V$. paradoxa is shea butter (francophone: le beurre de Karité), which is extracted from the dried kernels. This oil is widely utilized locally for domestic purposes such as cooking, as a skin moisturizer and as an illuminant [4]. Shea butter is also utilized commercially as an ingredient in cosmetic, pharmaceutical and edible products [6]. The shea tree (Vitellaria paradoxa) is one of such indigenous wild fruit trees with enormous nutritional benefits. The fruit pulp and oil from the shea nuts have been reported to be vital for supporting the livelihoods of the parklands communities $[7,8]$. The fruit is edible with a nutritious sweet and spice able flavour pulp. The fruit pulp is also a source of food for other animals such as elephants, sheep, pigs, bats and birds [9]. Apart from the fruit playing an important role in the diets it is also sold in local markets [10]. These trees are important traditional sources of fruits, beverages, nuts and edible oil [11]. The nutritional value of indigenous fruit bearing tree species indicates that many are rich in sugars, essential vitamins and minerals while some of their seeds are high in edible oil and proteins. The seeds have the potential of serving as the main source of edible vegetable oil for many rural people and in the economy of many countries. The shea tree does not only provides shea fruits, kernels and butter but it is also a source of fuel (charcoal), shade, medicine, traditional apiculture for placing hives and traditional cultural ceremonies [8]. Other parts of the tree such as sap, leaves and roots have industrial potential application [9]. Fruiting of the tree commences only after 15-20 years [12] and reaches full maturity after 45 years [13]. The trees fruit at the end of the dry season and are harvested during rainy season between the months of May and August [14]. The fruit takes 4-6 months to develop and each tree produces $15-20 \mathrm{~kg}$ of fruits [12]. The ripening improves the taste to the sweet pear taste and the colour is greenish-yellowish with ellipsoidal shape $(10-15 \mathrm{~cm})$ or spherical berry with two to three grains per fruit. According to Maranz et al., FAO, Kapseu et al. [8, 10, 15], the pulp of the fruit is edible with sweet and spice able flavour, play an important role in the local diet, can also be sold in the local markets and can be used as a source of food for other animals such as elephants, sheep, pigs, bats and birds. Each fruit contains a kernel with oval or round hard red brown or dark brown seed referred to as a "shea nut". The fresh nut size and shape of particular trees are distinctive [16] and contains $41 \%$ water, $18 \%$ residue, $21 \%$ oil and $20 \%$ husk [9]. The shiny, smooth and fragile shea nut shell is always processed into the "shea kernel" whereby each tree can yield 3-6 kg $[17,10]$. The shea kernels are the main source of shea butter, sold for income and used as medicine [9, 10]. Having a high melting point of between $\left(32-45^{\circ} \mathrm{C}\right)$ and being close to body temperature are attributes that make it particularly suitable as a base for ointments and medicines [18].

Insect pests can damage and affect the quality of the shea fruit in storage. In many developing countries including Nigeria, it is estimated that $40-45 \%$ of crops are lost to pests, diseases and inadequate storage before they reach the market. Consequently, this could threaten food security, self sufficiency and incomes. Reduction of post-harvest losses from the shea fruit can increase its availability, decrease the area needed for its cultivation, and conserve natural resources. In their investigation of the occurrence and diversity of hemi-parasitic plants, vertebrate and insect pest species of Vitellaria paradoxa encountered 33 insect species from 17 families in the ecological zones of moist wood-land (Derived) Savanna, dry wood land (derived) savanna and southern guinea savanna [19]. They found Cirina forda (Saturnidae: Lepidoptera) to be a major pest causing 60-90\% defoliation of mature trees of $V$. paradoxa. However, Odebiyi et al. did not report the incidence of insect pests of shea fruits in storage, in their studies [19].

This study evaluates the population dynamics of insect pests associated with the shea nut and proffers improvement on indigenous storage systems to guarantee long term storage.

\section{Objective of the Study}

1) This study evaluates the population dynamics of insect pests associated with the shea fruit.

2) Proffers improvement on indigenous storage systems to guarantee long term storage.

\section{Materials and Methods}

Shea fruits were collected from Bida, Niger State and taken to the entomology laboratory located in the Nigerian Institute for Oil Palm Research (NIFOR). They were placed in a black polyethylene bag and kept in a metal cage where 
observations were conducted for storage pests on a monthly basis for 12 months (October 2014-November 2015) with temperatures fluctuating between $26^{\circ} \mathrm{C}-34^{\circ} \mathrm{C}$ with a mean of $29.51^{\circ} \mathrm{C}$ and relative humidity from $52 \%-92 \%$ with a mean of 77.06\%. On a monthly basis between October 2008 and September 2009, 10 fruits were removed and observed under a Wild Heerbrugg M 3B Binocular Microscope equipped with a standard ocular micrometer. In addition, a Samsung camera S760, 7.2 Mega pixels was utilized.

Niger State was divided into zones (A-C) for effective coverage of storage warehouses. Selected warehouses were visited, observations made, shea fruits collected for laboratory analysis and the owners interviewed. The method used emphasized a participatory approach, facilitating greater local involvement in the collection of data that serves the purpose of gaining an insider's perspective. Direct observation of infrastructural facilities also assisted in validating information gained from respondents.

\section{Sampling Procedures}

The State was divided into zones and four farmers were visited representing different communities that fit into the following criteria:

1. Two farmers have warehouses that are relatively large and are big dealers; and

2. Two farmers have warehouses that are relatively small and are small dealers/agents, living farther away into the rural area.

\section{Results and Discussion}

Once fruits are ripe, they fall down by themselves beneath the mother tree and it is left to become over ripe [12]. During harvesting, the shea fruits are mainly collected from the ground by village women and children who move long distances from home to pick and gather them under the trees. The children and women eat the pulp and remove the seed kernel. The shea fruits can be collected from as near as the homestead and as far as $10 \mathrm{~km}$. The collected fruits can then be transported in lots of $20 \mathrm{~kg}$ to the village where processing takes place [12]. The shea nuts are usually sun dried for 1-2 weeks and dehusked to obtain the shea kernel which is further sun dried for another 1-2 two weeks. Although the shea kernels can sometimes be baked to concentrate the oil in the kernel and lengthen the storage period, this has been discouraged because it is a limiting factor to quality of shea butter. Methods of solar drying on polythene sheeting have been developed in some African countries, but they have limited durability [20]. The fresh mature fruit of the shea tree is covered externally by the pulp consisting of an epicarp (greenish) and a mesocarp (yellowish). De-pulping is the removal of the pulp (the epicarp and the mesocarp) when the shea fruit is ripe. The pulp which is mostly green becomes soft when the fruit ripens [21]. Raw shea butter is obtained primarily by the traditional method of extraction [22], from the shea fruit kernel, but can also be obtained by mechanical [23], enzymatic [24] and chemical methods [25].

A total of 126 mites were sighted during the period under review (Table 1). October (25) and November (21) 2014 had the highest number of mites while no mites were recorded in September 2015. It was observed that the numbers of mites sighted were reducing with the length of storage. The mites were initially robust and fresh. However, with progress in time, they were less robust suggesting that water loss of the nuts had a profound effect on their physiological processes.

Table 1. Indicates mean number of mites observed in shea fruits

\begin{tabular}{ccc}
\hline Date & Number of mites & Mean \\
\hline $15 / 10 / 14$ & 25 & 2.5 \\
$14 / 11 / 14$ & 21 & 2.1 \\
$5 / 12 / 14$ & 18 & 1.8 \\
$23 / 1 / 15$ & 14 & 1.4 \\
$9 / 2 / 15$ & 10 & 1.0 \\
$16 / 3 / 15$ & 10 & 1.0 \\
$22 / 4 / 15$ & 10 & 1.0 \\
$11 / 5 / 15$ & 9 & 0.9 \\
$10 / 6 / 15$ & 8 & 0.8 \\
$27 / 7 / 15$ & 8 & 0.8 \\
$27 / 8 / 15$ & 3 & 0.3 \\
$30 / 9 / 15$ & 0 & 0 \\
Grand total & $\mathbf{1 2 6}$ & $\mathbf{1 . 2 6}$ \\
\hline
\end{tabular}


According to USAID [9], the shea kernels can be stored for several years without spoilage by maintaining its moisture content between $6 \%$ and $7 \%$. This is so because the drying process inactivates enzymes responsible for the build-up of fatty acids in the seed kernel USAID [9]. Shea kernels are stored in sacks, woven baskets and plastic buckets that are stored either in house, granary or kitchen floors. Sometimes the kernels are hanged in houses or kitchens instead of floors. In West Africa, jute bags from cocoa industry are widely applicable. Over the past decades, polythene bags or sacks have come into wide use for storage of shea kernels. However, this has been reported to stimulate fungal growth important for quality because they do not allow air circulation [20]. Moreover, because of the recalcitrant properties of shea nuts, it storage is very difficult [12].

Other insect pests were also recorded (Table 2).

Table 2. Shows other insect pests observed in shea fruits

\begin{tabular}{ccccc}
\hline Date & No of Shea nuts & Insect species recorded & Number recorded & Stage of development \\
\hline \multirow{2}{*}{$9 / 2 / 15$} & \multirow{2}{*}{10} & Chalcid ants & 9 & Adult -4 \\
& & & Larva -4 \\
Pupa -1 & Larva -4 \\
$16 / 3 / 15$ & \multirow{2}{*}{10} & Weevils (Curculionidae) & 7 & Pupa -3 \\
\hline
\end{tabular}

As storage time increased, the nuts began to shrink. This is probably due to reduced moisture levels. After 7 months, effects of insect boring begin to emerge in the nuts. Outer shell coverings showed signs of de-scaling. After 10 months, scale covering of the nuts started breaking off thereby exposing the bare nuts and disease spores start appearing (Plate 1).

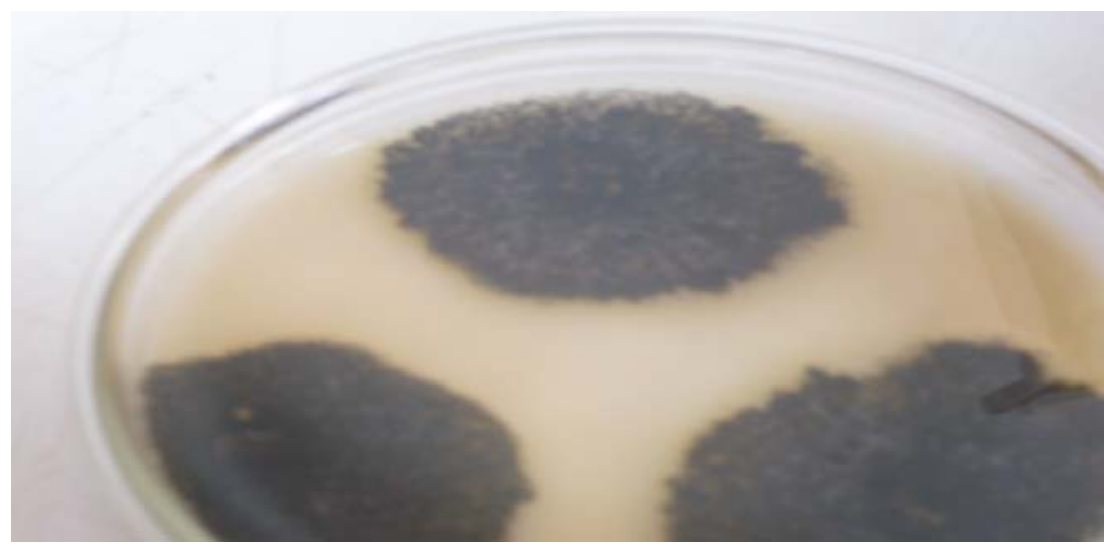

Plate 1. Aspergilus on Shea nut.

After 11 months, some of the nuts started physical disintegration into dust. After 12 months, the nuts become very dry and further disintegrated with no observed insect pest.

It was observed that the mites were the most common pests encountered. The chalcid ants were only sighted in fifth month while the weevils (Curculionidae) were observed in the sixth month.

Figure 1 and Figure 2 show weevils and chalcid ants.

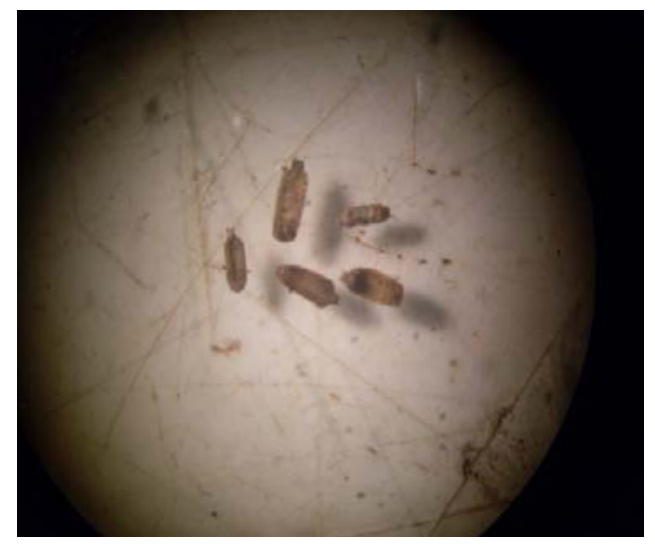

Figure 1. Weevils (Curculionidae).

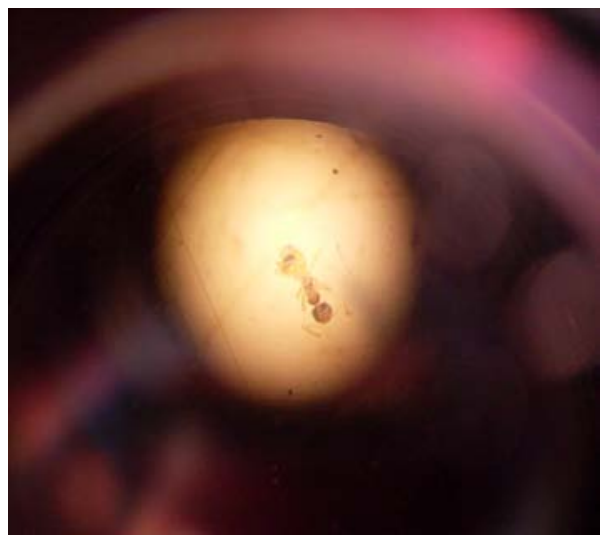

Figure 2. Chalcid ant. 
Stored shea fruits are susceptible to pest infestations if adequate control measures are not taken. However, to avoid losses, clean facilities are of importance in storing the fruits.

Environmental pollutants, especially excessive use of chemicals should be avoided.

Good agricultural practices which entail basic food safety principles associated with minimizing biological, chemical and physical hazards from the field and throughout the distribution chain of the shea fruit should be ensured. Hygienic practices necessary to protect against contamination of the shea fruit from direct or indirect sources is recommended to reduce microbial contamination.

Generally, fresh fruits harbour a large number of insects during post-harvest handling. Irradiation could increase the shelf life of the shea fruit. Most insects become sterile when subjected to irradiation doses ranging between 50 and 750Gy. Irradiation doses of 250Gy can be tolerated by most fresh fruits with minimal detrimental effects on quality [26]. However, the effects of irradiation on shea fruits were not tested in this study.

\subsection{Warehouse Inspections on Stored Shea Fruits}

Issues of variability in quality of shea butter oil due to post harvest handling practices such as drying and storage have been raised by [4] and [8]. The high moisture content of the shea kernel due to poor drying conditions and storage has been reported to increase the free fatty acids of the shea oil resulting into poor quality [9]. According to FAO and CFC [20], parboiling is a process meant to deactivate enzymes responsible for formation of free fatty acid before sun drying.

Warehouses inspected include the following:

\subsubsection{Zone A-Bida Area: Anfani village}

Name of farmer: Alh. Aliyu Abubakar Anfani, 75 years. He has 3 big stores with capacities of 120 tonnes (1,560 bags); 120 tonnes (1,560 bags); and 90 tonnes (1,170 bags). He has never noticed fungal or insect infestation. He gets his stock from agents who go from village to village buying from pickers. He buys a measure of shea kernel for \#200 (fresh) and \#450 (dry). He added that there are 10-15 measures per bag; and a trailer takes about 30 tonnes. He sells 3-5 trailer loads/year. One tonne of dry kernel sells for \#60,000. His customers export the shea kernels to Germany where they are processed. Alh. Aliyu mentioned that the dry kernel do not want sun or rain explaining that the sun evaporates the oil thereby producing less butter while the rain encourages mold infestation causing decay. He concluded by saying that big time customers provides him with insecticides and his business is profitable.

His income per annum was calculated to be between \#4.6 million and 7.0 million.

\subsubsection{Zone A-Old market street, Bida town}

Name of farmer: Alh. Tanko Attahiru, 45 years, inherited the shea business from his father. His warehouse capacity is 5,850 bags. He gets his stock through agents who go to villages buying from pickers who are mainly women during the season. The season is usually between June and November. He stated that he usually dries the fresh shea fruits inside the warehouse. No insecticide is used. His major challenge is spoilage when FFA is high. The fruits can be stored for up to 2 years if the price is low. His customers are mainly from Nnewi, Port-harcourt (Industrialists), Japan, India (Exporters), and local processors. Sorting is done and lower grades are usually sold to local processors. He sells at least 100 trailers per year. Exporters buy 50-70 trailer loads per year. He buys at \#60,000 per tonne (off season) and \#40,000 per tonne (during season). Figure 3 shows bags of shea nuts on the bare floor. Figure 4 shows windows without wire gauze net.

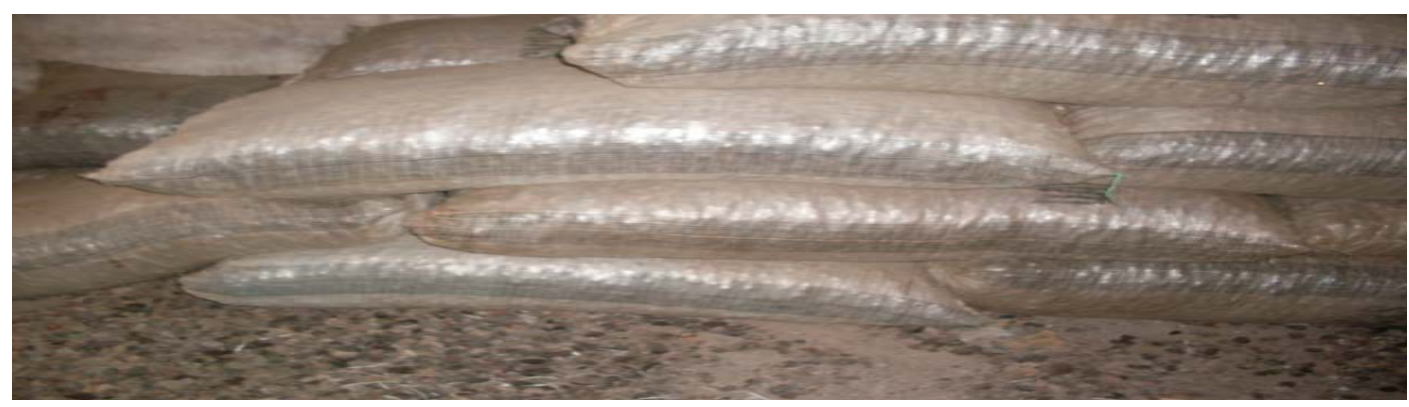

Figure 3. Show shea bags on the ground. 


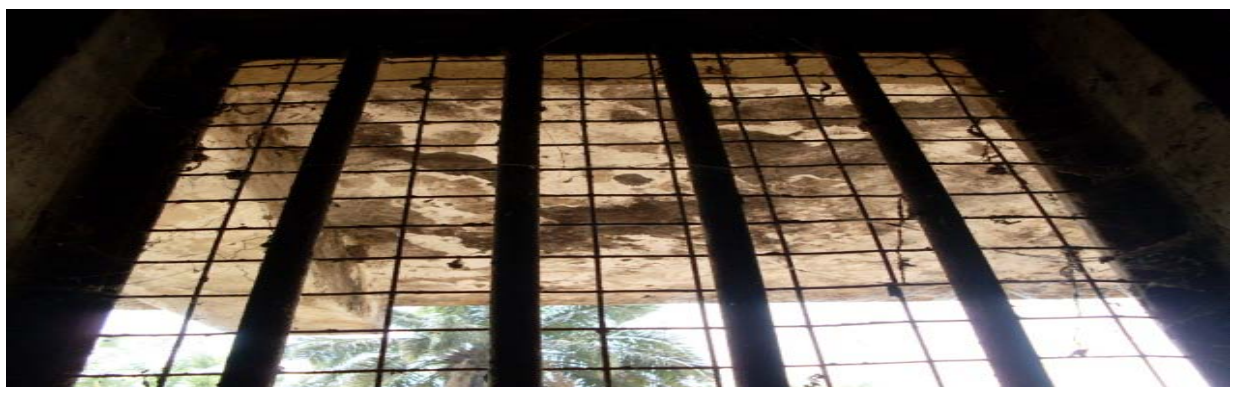

Figure 4. Shows window without wire gauze net.

\subsubsection{Zone A-Gboko L. G. A., Lemu village}

Name of farmer: Alh. Umar Wushishi, 55 years, inherited the shea business from his father. Stores his shea fruits outdoors during the dry season and hires stores for storage during the rainy season. Figure 5 shows outdoor storage of shea nuts.

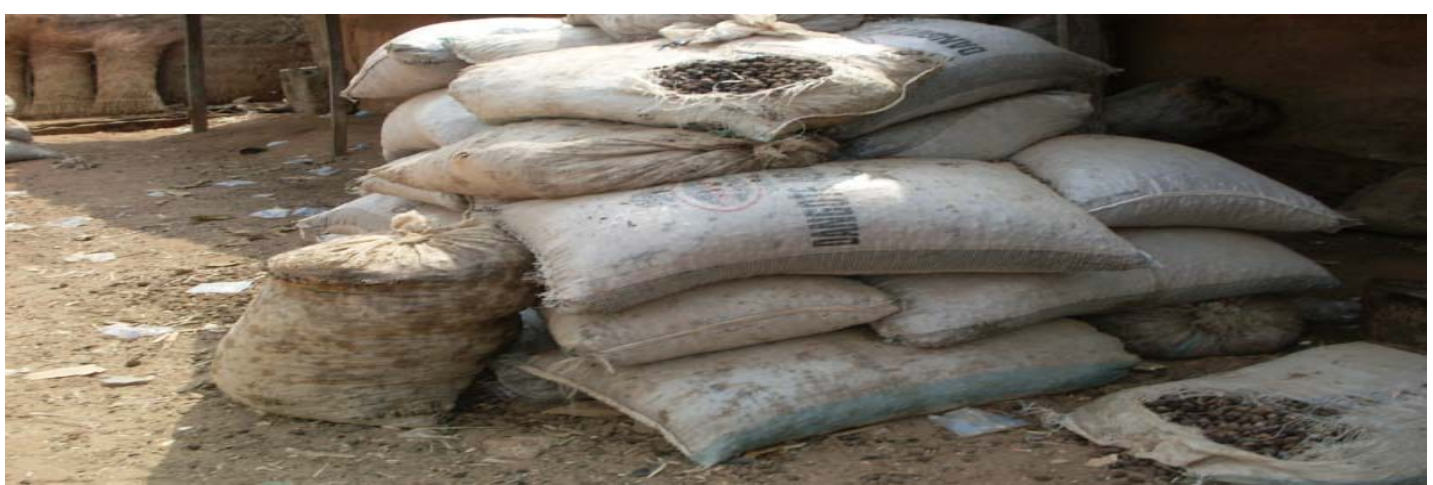

Figure 5. Shows outdoor storage of shea nuts.

Bigger dealers keep products in his custody until it is evacuated. He also has customers from Port-harcourt and Cotonou. He sells a bag of shea fruit between \#800 and \#1,200 per bag depending on demand. Also, when cocoa does well, price of shea goes down and vice-versa. He stated that there are differences in the shea butter depending on processing method which include:

A. Local oven: Butter looks black;

B. Parboiled: Pure;

C. Sundried: Quantity of oil smaller than parboiled.

He buys during season at \#25,000 per tonne and sells at \#30,000 per tonne. He buys up to 20 trailers per year. He does not sort into different grades and uses no insecticide. His challenges are that there is more spoilage outside as bags do not last and he needs a standard warehouse.

\subsubsection{Zone C-Wushishi}

Name of farmer: Alh. Barde, 65 years. He has been in the business since the 1960's. Capacity of his 2 stores is 30 tonnes. The store is a cemented (24' x 12') mud house with no windows and no door. Figure 6 shows the store without window or a door.

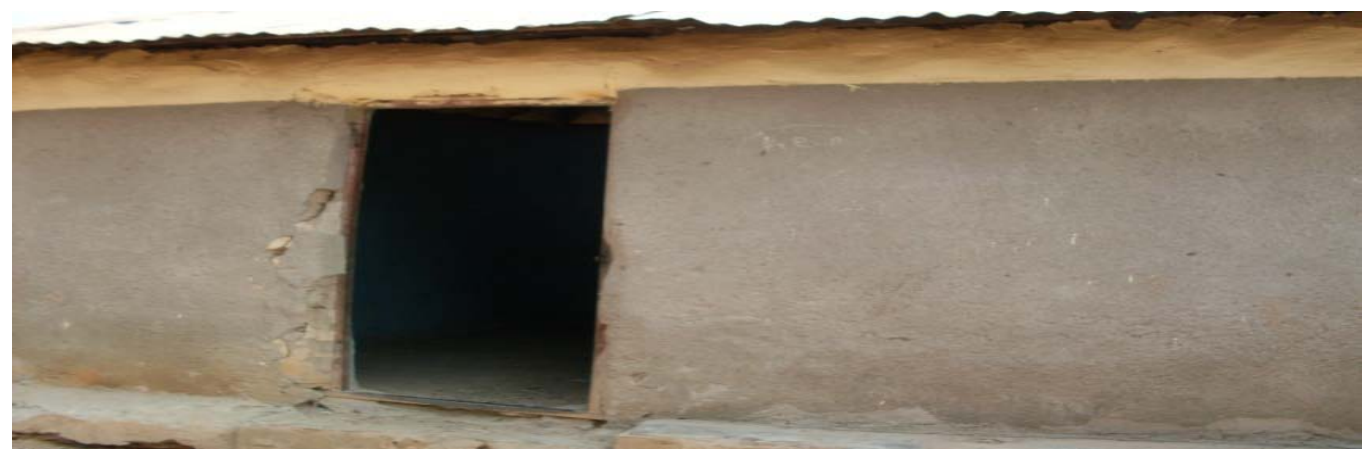

Figure 6. Shows store without window or door. 
He buys directly from pickers as well as from agents. A measure (Nania) costs \#240 and 14 measures makes a bag. He stocks 30 trailers per year at a cost of \#45, 000 per tonne. During the season, he sells at \#30, 000. His customers are from Cotonou and India. His warehouse capacity is 40 tonnes. He has not observed fungal or insect pests and uses no insecticide. He does not sort into different grades. His major challenge is capital.

\section{General Observations}

1. The warehouses were not properly sealed. There are continuous openings between the roof and block wall. Lizards, rodents and insects have access to the stored kernels.

2. Dry kernel bags were placed on the bare floor of the stores.

3. The dry shea kernels were not sorted into grades.

4. The walls of the stores were not plastered.

5. The doors and windows were not sealed with nets to prevent entry of insects.

\section{Conclusion}

Recommendations for Improved Storage of Shea Fruits: A number of measures must be taken to improve the storage of shea fruits and they include:

1. The shea fruits should be picked immediately as it matures, as fruits left in the fields for long periods become infested.

2. During collection, it should be ensured that the fruits are not exposed to insect pests before they are properly bagged and removed.

3. All infested shea fruits should be removed and separated immediately. Particular attention should be paid to cracks and gaps where insects may hide.

4. The fruits should be properly dried before storage to prevent germination and fungi attack.

5. Stores should be sited from any potential source of infestation. Windows and doors should be sealed with insect proof gauze, and bags placed on wooden layers to prevent dampness rising from the ground.

6. Stores must be airy, cool and dry. The walls, roof and floor should be both water tight and rat proof. Temperature variations should be minimal to discourage condensation of water which promotes fungus development.

7. Always keep the store and the surroundings clean. If possible, it should be fumigated and disinfected.

8. Periodic inspection (weekly to fortnightly) and removal of infested fruits is important. Particular attention must be paid to cracks and bag seams when looking for insects.

9. Infection with fungi can be detected by the moldy smell, which is noticeable even before any visual changes to the fruits can be seen.

\section{Competing Interests}

Authors have declared that no competing interests exist.

\section{References}

[1] Salle, G., A. Boussin, A. Raynal-Roques, and F. Brunck. (1991). Le karite': e'tat de nos connaissances et perspectives de recherche. Pages 427-439 in Riedacker, A., E. Dreyer, C. Pafadnam, H. Joly, and G. Bory (eds.), Physiologie des arbres et arbustes en zones arides et semi-arides. John Libbey Eurotext, Groupe d'Etude de l'Arbre, Paris.

[2] Hall, J. B., D. P. Aebischer, H. F. Tomlinson, E. Osei-Amaning, and J. R. Hindle. (1996). Vitellaria paradoxa: A monograph. School of Agricultural and Forest Sciences, University of Wales, Bangor, U.K., p. 105.

[3] Mohammed S, Heijndermans E, Butter S, Group P. (2013). Behind the Butter: An energy analysis of shea butter processing. SNV Ghana. http://www.snv.org/public/.

[4] Lovett, P., N. and Haq, N. (2000). Diversity of shea nut trees (Vitallaria paradoxa C. F. Gaertn.). In Ghana. Genetic Resources and Evolution 47: 293-304.

[5] CAB International. (2003). Introgression from genetically modified plants into wild relatives and its consequences, ed./H.Nijs; D. Bartsch.

[6] Abbiw, D. K. (1990). Useful plants of Ghana, West African uses of wild and cultivated plants. Intermediate Technology Publications and The Royal Botanic Gardens, Kew, London. pp. 66-67.

[7] Okullo, J., B., L., Hall, J., B., Obua, J. (2004a). Leafing, flowering and fruiting of Vitellaria paradoxa subsp. nilotica in Savanna parklands in Uganda. Agroforestry Systems, 60, 77-91.

[8] Maranz, S., Kpikpi, W., Wiesman, Z., Sauveur, A., D., Chapagain, B. (2004). Nutritional Values and Indigenous Preferences for Shea Fruits (Vitellaria Paradoxa C.F. Gaertn. F.) in African Agroforestry Parklands. Journal of Economic Botany, 58(4): 588-600. 
[9] USAID. (2004). Shea butter value chain, production transformation and marketing in West Africa. WATH Technical report No. 2.

[10] FAO. (2007). Corporate Document Respiratory. Minor oil crops http://www.fao.org/docrep/X5043E/x5043E0b.htm. Retrieved on 23.3.2007.

[11] Okafor, J. C. (1985). Selection and improvement of indigenous topical trees. J. Trop. Resour., 1: 87-95.

[12] Karin, L. (2004). Vitallaria paradoxa and feasibility of shea butter project in the North of Cameroon. Master of Science thesis submitted to the University of Montana. USA.

[13] FAO. (2001). Traditional food plants. FAO Food and Nutrition Paper, 42, 1-593.

[14] Okullo, J. B. L., Nkuttu, D., Agea, J. B., Obua, J., Lovett, P., Masters, E., Haze, J. B., \& Teklehaimanot, Z. (2004b). Utilisation \& Conservation of Indigenous tree species in Agro forestry Parkland of Northern Uganda.

[15] Kapseu, C., Bup, N. D., Tchiengang, C., Abi, C. F., Broto, F., and Parmentier, M. (2007). Effect of particle size and drying temperature on drying rate and oil extracted yield of Buccholzia coriacea (MVAN) and Butyrospermum parkii (ENGL). International Journal of Food Science and Technology, 42: 573-578.

[16] Boffa, J. M., Yameyogao, G., Nikiema, P., and Knudson, D. M. (1999). Shea nut (Vitelaria paradoxa), Production and collection agroforestry parkland Bukina Faso.

[17] Leakey, R. R. B. (1999). Potential for novel products from agroforestry trees: a review. Food Chemistry, 66: 1-14.

[18] Bonkoungou, E. G. (1987). Monographie du karité, Butyrospermum paradoxum (Gaertn. f.) Hepper, espèce agroforestière à usages multiples. Institute de la Researche en Biologie et Ecologie Tropicale, Centre National de la Researche Scientifique et Technologique, Ougadougou. p. 69.

[19] Odebiyi, J. A., Bada, J. A., Omoloye, A. A., Awodoyin, R. O., and Oni, P. I. (2004). Vertebrate and insect pests and hemi-parasitic plants of Parkia biblobosa and Vitellaria paradoxa in Nigeria, Agroforestry Systems 60: 51-59.

[20] FAO and CFC. (2005). International Workshop on Processing and Marketing of Shea Products in Africa. Proceeding of a Workshop held by the Food and Agriculture Organization of the United Nations, the Common Fund for Commodities and the Centre de suivi ecologique; Technical Paper no. 21. CFC (Netherlands), Dakar (Senegal), 4-6 Mar 2002/FAO, Rome (Italy), 2004.

[21] Gyedu-Akoto E., Amon-Armah F., Yabani D. (2017). Utilization of shea fruit to enhance food security and reduce poverty in Ghana. African Journal of Science, Technology, Innovation and Development, 9(6): 697-705.

[22] Abdul-Mumeen I., Zakpaa H. D., Mills-Robertson, F. C. (2013). Biochemical and microbiological analysis of shea nut cake: A waste product from shea butter processing. Journal of Agricultural Biotechnology and Sustainable Development, 5(4): 61-68.

[23] Olaniyan A. M., Oje K. (2007). Development of mechanical expression rig for dry extraction of shea butter from shea kernel. Journal of Food Science and Technology, 44: 465-470.

[24] Didia, B., Zakpaa, H. D., Mills-Robertson, F. C., Iddrisu, A. M. (2018). Enzyme-assisted traditional extraction of shea butter using different levels of pre-treated shea kernels. Journal of Agricultural Biotechnology and Sustainable Development 10(1): 1-10.

[25] Apea, O. B., and Larbi, E. (2013). Indigenous Technology and Scientific Research as Ingredients for Economic Development: A Case of Shea Butter Industry. Journal of Contemporary Integrative Ideas, 1(1): 16-26.

[26] Adel, A. K. and Rosa, S. R. (2004). The role of post-harvest management in assuring the quality and safety of horticultural produce. F.A.O. Services Bulletin. p. 52. 